\title{
Diversity and Distribution of the Genus Platypeltoides (Nileidae) in Morocco
}

\author{
Joan Corbacho Amado ${ }^{1}$, Francisco J. López-Soriano ${ }^{2}$, Ulrich Lemke ${ }^{1}$, Scott Morrison ${ }^{3}$, \\ Keith Hammond ${ }^{1}$ \\ ${ }^{1}$ Geological Museum of the Seminary, Barcelona, Spain \\ ${ }^{2}$ Department of Biochemistry and Molecular Biomedicine, Faculty of Biology, University of Barcelona, Barcelona, Spain \\ ${ }^{3}$ Department of Geological Sciences, University of Oregon, Eugene, USA
}

Email address:

fosilart@hotmail.com (J. C. Amado)

\section{To cite this article:}

Joan Corbacho, Francisco J. López-Soriano, Ulrich Lemke, Scott Morrison, Keith Hammond. Diversity and Distribution of the Genus Platypeltoides (Nileidae) in Morocco. American Journal of Bioscience and Bioengineering. Vol. 6, No. 2, 2018, pp. 6-13. doi: $10.11648 /$ j.bio.20180602.11

Received: August 13, 2018; Accepted: September 5, 2018; Published: October 13, 2018

\begin{abstract}
Recently two new species of the genus Platypeltoides (Nileidae, Trilobita) from the Anti-Atlas region of Morocco have been described. Because new material is still appearing in this area, we have considered to review this subject. The aim of this article is to describe all the species of the genus Platypeltoides appeared in the Lower Fezouata Formation (Tremadocian, Lower Ordovician) and distributed in three different locations of the Moroccan Anti-Atlas. Several specimens of this genus and kept in the Museo Geológico del Seminario (Barcelona, Spain), Museo Geominero (Madrid, Spain) and the Natural History Museum (London, UK) are here described and discussed. In this paper, all known species of the Platypeltoides genus of Morocco are presented. All them appear in the Zagora region and in the Guelmim area. Three species have already been described: P. magrebiensis?, P. hammondi and P. carmenae. We left two more in open nomenclature, Platypeltoides aff. carmenae and Platypeltoides sp. Finally, another species changes its genus: Asaphellus cuervoae = Platypeltoides cuervoae. Indeed, four species (but possibly two more) of the genus Platypeltoides are present in the Lower Ordovician of Morocco.
\end{abstract}

Keywords: Trilobita, Platypeltoides, Palaeozoic, Tremadocian, Morocco

\section{Introduction}

In the last two years, we have described two new species of Platypeltoides from the Lower Ordovician (Tremadocian) of the Fezouata Shale of Morocco: P. hammondi Corbacho \& López-Soriano, 2016 [1] and P. carmenae Corbacho et al., 2017 [2]. After obtaining two new species, we have decided to write this article, which is a part of the project that, since 2005, we have been developing on the study of the trilobites of the Ordovician of Morocco, supported by the Museo Geológico del Seminario de Barcelona (Spain) and the Department of Paleontology of the Associació de Perits i Taxadors de Catalunya (Spain), founded by one of the autors (JC).

Historical Background

The first geological research done in Morocco was carried out by the French geologist Henri Coquand (1813-1881), who collected and described the first fossils [3]. The presence of Ordovician rocks in the Anti-Atlas zone was firstly mentioned by Neltner [4], specifically in the Tafilalt area. Similarly, it was established the existence of the Ordovician system both in the western (Jbel Tachilla, Tiznit area [5]) and central Anti-Atlas (Foum Zguid area; Bondon in [6]).

A long list of authors have studied the trilobite faunas from the Upper and Middle Ordovician of Morocco: Barthoux [7], Termier [6, 8], Neltner [4], Roch [9], Destombes [10-13], Destombes et al. [14] and Rábano [15], and more recently Vela and Corbacho [16], Corbacho [17], Corbacho and Kier [18], López-Soriano and Corbacho [19], Corbacho and López-Soriano [20], Corbacho and Calzada [21], Corbacho et al. [2, 22], and Fortey and Edgecombe [23]. On the other hand, the studies on the trilobites from the Lower Ordovician of Morocco have been carried out by Pruvost (in [24]), Termier and Termier [25], Hupé (in [26]), Destombes [12, 13, 
27-35], Destombes et al. [14], Rábano [15], Vidal [36-38], Vela [39], Vela and Corbacho [40], Corbacho [41], Fortey [42-44], Corbacho and Vela [45-47], Corbacho and LópezSoriano [1, 48], and Corbacho et al. [2]. See also Basse [49] and Lemke [50] for the described species.

The described species of the genus Platypeltoides in Morocco are: Platypeltoides magrebiensis? Rábano, 1990; Platypeltoides cuervoae (Corbacho \& López-Soriano, 2012); Platypeltoides hammondi Corbacho \& López-Soriano, 2016; and Platypeltoides carmenae Corbacho et al. 2017.

\section{Materials and Methods}

\subsection{Origin of the Specimens}

The specimens examined in this study originate from AntiAtlas, Morocco and belong to the Lower Ordovician (Tremadocian), Lower Fezouata Formation. All the sites mentioned in this study have been visited by the first author (JC). The images of the holotypes of the different species from the cited publications are presented. Platypeltoides magrebiensis? is also represented by the paratype (MGM902X) conserved in the Museo Geominero of Madrid (Spain) and an authentic specimen (MGSB-JC224) conserved in the Museo Geológico del Seminario of Barcelona (Spain) and $P$. cuervoae two paratypes are also presented (MGSBJC76 and MGSB-JC77) conserved in the Museo Geológico del Seminario of Barcelona (Spain) and one (NHMUKit28945) conserved in the Natural History Museum of London (UK).

\subsection{Preparation and Treatment of Specimens}

All the specimens presented in this study, except the holotype and paratype of $P$. magrebiensis, have been obtained and worked by Moroccan specialists for the first author (JC).
All specimens, except $P$. magrebiensis?, have been treated with ammonium chloride to highlight their details (the quality of the figures of $P$. magrebiensis? has been improved through the PhotoScape software). A Canon digital camera, model EOS $1100 \mathrm{D}$, has been used to take the pictures. For the coordinates, a Garmin GPS Foretrex 401 model has been used.

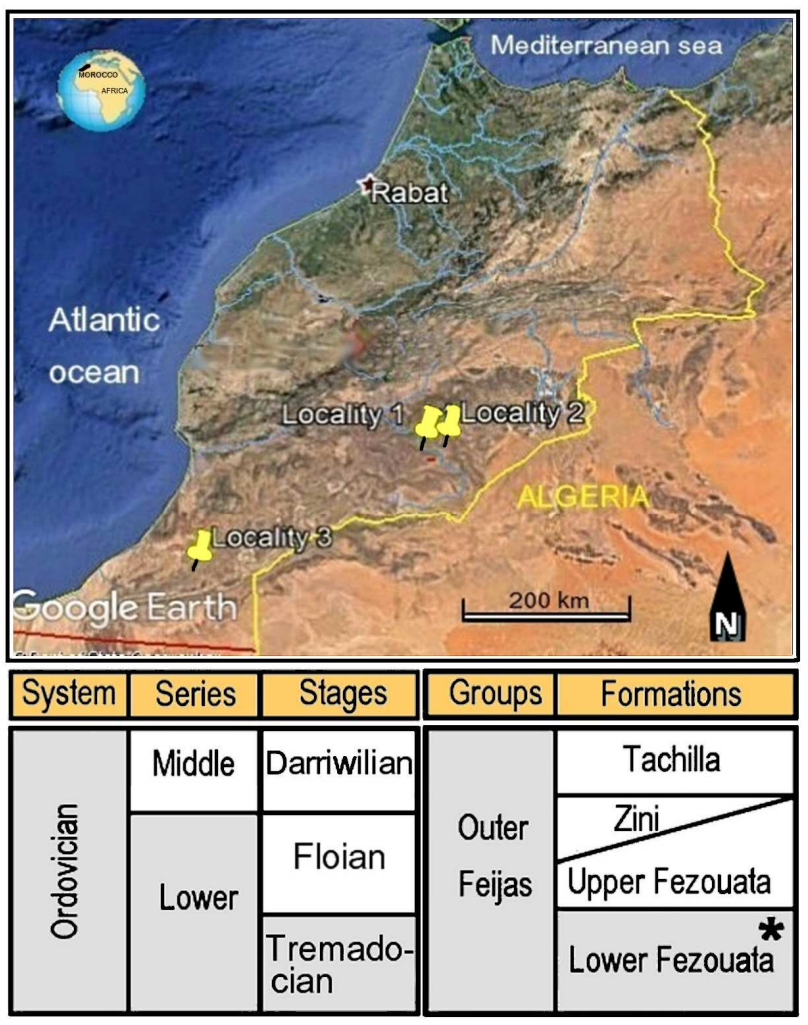

Figure 1. Map of Morocco and Stratigraphy of Lower Ordovician from the Anti-Atlas. The number on white circles indicate the localities: (1) Platypeltoides magrebiensis?, P. hammondi; (2) Platypeltoides $s p$. and Platypeltoides aff. carmenae; (3) P. carmenae and P. cuervoae.

Table 1. Measurements ( $\mathrm{mm}$ ) of the different species of Platypeltoides from Morocco.

Platypeltoides magrebiensis?

\begin{tabular}{|c|c|c|c|c|c|c|c|c|c|c|c|c|}
\hline Specimen number & TL & EL & CL & DEC & $\mathbf{C W}$ & CW1 & GW & FWG & PW & RW & $\mathbf{R L}$ & PL \\
\hline MGM901X & 53 & 8 & 20 & 6 & 33 & 24 & 13 & 18 & 27 & 9 & 14 & 17 \\
\hline MGM902X & 277 & 24 & 98 & 27 & 152 & 122 & 41 & 52 & 130 & 44 & 64 & 88 \\
\hline MGSB-JC224 & 235 & 21 & 78 & 17 & 120 & 90 & 50 & 70 & 130 & 34 & 60 & 70 \\
\hline
\end{tabular}

Platypeltoides hammondi

\begin{tabular}{|c|c|c|c|c|c|c|c|c|c|c|c|c|}
\hline Specimen number & TL & EL & CL & DEC & $\mathbf{C W}$ & CW1 & GW & FWG & PW & RW & $\mathbf{R L}$ & PL \\
\hline MGSB-82122 & 165 & 17 & 50 & 20 & 129 & 80 & 37 & 50 & 74 & 24 & 42 & 54 \\
\hline
\end{tabular}

Platypeltoides carmenae

\begin{tabular}{|c|c|c|c|c|c|c|c|c|c|c|c|c|}
\hline Specimen number & TL & EL & CL & DEC & CW & CW1 & GW & FGW & PW & RW & RL & PL \\
\hline NHMUK-it29220 & 220 & 25 & 94 & 22 & 180 & 112 & 50 & 76 & 124 & 33 & 50 & 66 \\
\hline
\end{tabular}

Platypeltoides cuervoae

\begin{tabular}{|c|c|c|c|c|c|c|c|c|c|c|c|c|}
\hline Specimen number & TL & $\mathbf{E L}$ & CL & DEC & $\mathbf{C W}$ & CW1 & GW & FWG & PW & RW & RL & PL \\
\hline NHMUK-it28944 & 125 & 16 & 44 & 16 & 210 & 68 & 30 & 44 & 76 & 24 & $\mathrm{X}$ & $X$ \\
\hline NHMUK-it28945 & 115 & 13 & 37 & 15 & 210 & 62 & 28 & 42 & 69 & 17 & 32 & 39 \\
\hline
\end{tabular}


Platypeltoides aff. carmenae

\begin{tabular}{lllllllllllll}
\hline Specimen number & TL & EL & CL & DEC & CW & CW1 & GW & FWG & PW & RW & RL & PL \\
\hline MGSB-KH2b & 155 & 15 & 57 & 19 & 138 & 84 & 34 & 50 & 88 & 23 & 40 & 50 \\
\hline
\end{tabular}

Platypeltoides sp.

\begin{tabular}{lllllllllllll}
\hline Specimen number & TL & EL & CL & DEC & CW & CW1 & GW & FWG & PW & RW & RL & PL \\
\hline MGSB-JC561 & 56 & 7 & 21 & 6 & 40 & 26 & 12 & 20 & 30 & 10 & 12 & 18 \\
\hline
\end{tabular}

$\mathrm{TL}=$ total exoskeleton length; $\mathrm{EL}=$ total eye lenght $\mathrm{CL}=$ total cephalon length; $\mathrm{DEC}=$ distance between the posterior eye side and the posterior cephalon side; $\mathrm{CW}=$ total cephalon width; $\mathrm{CW} 1=$ maximun cranidium width (in posterior margin); GW = basal glabela width; FWG = frontal glabela width in the widest part; $\mathrm{PW}=$ máximum pygidium width; $\mathrm{RW}=$ anterior width of the pygidial rachis; $\mathrm{RL}=$ total length of pygidial rachis; $\mathrm{PL}=$ total pygidium length.

\section{Systematic Paleontology}

The specimens indicated under the entries MGSB are housed in the collections of the Museo Geológico del Seminario de Barcelona (Spain), those indicated under the entries NHMUK are housed in the Natural History Museum of London (UK), and those indicated under the entries MGM are housed in the Museo Geominero de Madrid (Spain).

Order ASAPHIDA Salter, 1864

Suborder ASAPHINA Salter, 1864 emend.

Fortey \& Chatterton, 1988

Superfamily CYCLOPYGOIDEA Raymond, 1925

Family NILEIDAE Angelin, 1854

Genus Platypeltoides Pribyl in Prantl \& Pribyl, 1949

Type species - Platypeltis croftii Callaway, 1877 from the Tremadocian of Shropshire (England, UK).

Geographical and stratigraphical distribution - The genus Platypeltoides is found in the Upper Cambrian, Tremadocian and Floian of Morocco, United Kingdom, Czech Republic, Sweden, Russia, Kazakhstan, China and Mauritania.

The oldest known species is Platypeltoides marginatus Appolonov \& Chugaeva, 1983 from the Upper Cambrian of Kazakhstan. Platypeltoides serus Tjernvik, 1956 from Hunnenberg in Sweden has an early Arenig age because of the occurrence with Ekeraspis armata and is the youngest membre of this genus. Furthermore, Platypeltoides sp. is reported from the Arenig of Mauritania [51, 52]. Most species are from the Tremadoc. Outside of Morocco, the following species are known:

Platypeltoides brevis (nomen nudum?) - Shineton Shales, Garmston, Shropshire, UK

Platypeltoides croftii (Callaway, 1877) - Shineton Shales, Shropshire, UK

Platypeltoides perseis Mergl, 2006 - Millina Formation,

Olesna, Bohemia, Czech Rep.

Platypeltoides primaevus (Lake, 1942) - Tynllan Beds, Porthmadog, Wales, UK

Platypeltoides sibirica Ogienko, 1992 - Siberian

Plattform, Russia

Platypeltoides uralicus Antsygin, 2001 - South Ural, Russia

Platypeltoides sp. Mergl, 2006 - Trenice Formation, Holoubkov, Czech Republic

The assignament of the fragmentary cranidium to
Platypeltoides, described by Peng, Geyer \& Hamadi [53] at the Mila Formation (Elbur's Mountains, Iran) is not certain. Platypeltoides has seven thoracic segments whereas Troedssonia has eight. Most of the species from China assigned to Platypeltoides belongs therefore to Troedssonia.

\subsection{Platypeltoides magrebiensis Rábano, 1990}

1969 Platypeltoides Destombes et al., pag. 152, plate 5, figure 1; plate 4, figure 14

1990 Platypeltoides magrebiensis Rábano, pag. 23, figure 1

2016 Platypeltoides magrebiensis? Corbacho \& LópezSoriano, pag. 15 , plate 2

Diagnosis - This species of the genus Platypeltoides is characterized by its large size, moderate relief, absence of a frontal border and a glabellar tubercle on the cephalon, and because it presents large eyes in the juvenile holaspis. The pygidium is smooth, showing only a poorly defined axial ring and a wide pygidial doublure, whose internal line develops in parallel to the pygidial margin [15].

Material - Three specimens are presented. The holotype $\mathrm{n}^{\circ}$ MGM901X (holaspis) has a total carapace length of $53 \mathrm{~mm}$ and the paratype $n^{\circ}$ MGM902X (false specimen) has a total carapace length of $277 \mathrm{~mm}$; they were used for the description of the species and are kept in the Museo Geominero de Madrid (Spain) [15]. The third specimen, with a total carapace length of $235 \mathrm{~mm}$, belongs to the collection of Joan Corbacho kept in Museo Geológico del Seminario de Barcelona (Spain) under the entry MGSB-JC224 (authentic specimen).

Geographical distribution - Upper part of the Lower Fezouata Formation. The studied locality exposes blue green argillites from the Upper Tremadocian, Lower Ordovician (Figure 1, locality $\mathrm{n}^{\mathrm{o}} 1$ ). The locality yielding the new trilobite is located approximately $32 \mathrm{~km}$ of the SE of Agdz and $14 \mathrm{~km}$ of the south of Tansikht, Dra Valley, Morocco. The coordinates of the excavation were $30^{\circ} 33^{\prime} 58^{\prime \prime} \mathrm{N}-6^{\circ} 9^{\prime} 55^{\prime \prime}$ $\mathrm{W}$ - Altitude $860 \mathrm{~m}$.

The following trilobite species also appear in this outcrop: Platypeltoides magrebiensis? Rábano, 1990; Asaphellus stubssi Fortey, 2009; Dikelokephalina brenchleyi Fortey, 2010; Hungioides sp.; Platypeltoides hammondi Corbacho \& López-Soriano, 2016; and Asaphellus sp. 


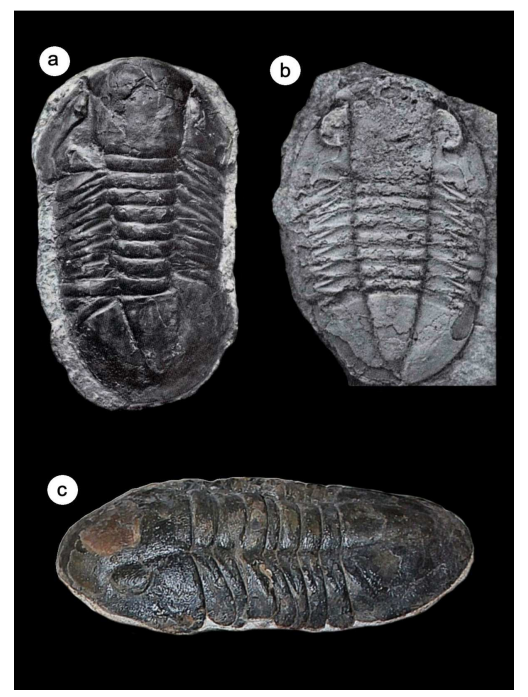

Figure 2. Platypeltoides magrebiensis? Outcrop $n^{\circ} 1$, Tansikht, Dra Valley. (a) Paratype $n^{\circ} M G M 902 X$ and (b) Holotype $n^{\circ} M G M 901 X$ (pictures taken from [15]; (c) Topotype $n^{\circ} M G S B-J C 224$.

\subsection{Platypeltoides hammondi Corbacho \& López-Soriano, 2016}

2016 Platypeltoides hammondi Corbacho \& LópezSoriano, pag. 13, plate 1

Diagnosis - Large-sized Platypeltoides with long genal spines, large eyes located slightly before of the transversal medium line of the cranidium and a completely smooth pygidium [1].

Material - Only a single individual (holotype) is presented. This is a moderately well-preserved individual which is kept in the collections of the Museo Geológico del Seminario de Barcelona (Spain), under the entry MGSB82122. Its total carapace length is $165 \mathrm{~mm}$.

Geographical distribution - Upper part of the Lower Fezouata Formation. The studied locality exposes blue green argillites from the Upper Tremadocian. The locality yielding the trilobite is located approximately $32 \mathrm{~km}$ of the SE of Agdz and $14 \mathrm{~km}$ of the south of Tansikht, Dra Valley, Morocco (Figure 1, locality $\mathrm{n}^{\mathrm{o}} 1$ ). The coordinates of the excavation were $30^{\circ} 33^{\prime} 58^{\prime \prime} \mathrm{N}-6^{\circ} 9^{\prime} 55^{\prime \prime} \mathrm{W}$ - Altitude $860 \mathrm{~m}$.

The following trilobite species also appear in this outcrop: Platypeltoides magrebiensis? Rábano, 1990; Asaphellus stubssi Fortey, 2009; Dikelokephalina brenchleyi Fortey, 2010; Hungioides sp.; Platypeltoides hammondi Corbacho \& López-Soriano, 2016; and Asaphellus sp.

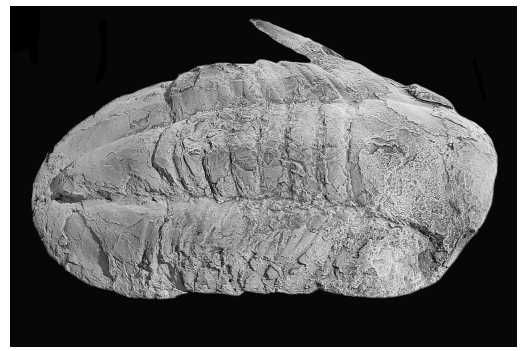

Figure 3. Platypeltoides hammondi. Outcrop $n^{o} 1$, Tansikht, Dra Valley. Holotype $n^{\circ}$ MGSB82122. Picture taken from [1].

\subsection{Platypeltoides carmenae Corbacho et al., 2017}

2017 Platypeltoides carmenae Corbacho et al., pag. 21, plates $1-4$

Diagnosis - Platypeltoides of large size, with a slightly subtriangular-shaped cephalon and medium-sized genal spines, large eyes located in the transverse median line of the cranidium, a thin anterior border and a slightly subtriangular pygidium with three axial rings and a terminal axial piece [2].

Material - Only a single individual (holotype) is presented. Total carapace length of $220 \mathrm{~mm}$, is kept in the collections of the Natural History Museum of London (UK), under the entry NHMUK-it29220.

Geographical distribution - The studied locality consists of grey-blue ferruginous sandstones which have been assigned to the Upper part of the Lower Fezouata Formation, Lower Ordovician (Upper part of Tremadocian). The studied site is located approximately $710 \mathrm{~km}$ of the SW of Rabat, in the administrative area of Agadir and NW of Assa in Guelmim area; Western Anti-Atlas, Morocco (Figure 1, locality $\mathrm{n}^{\circ} 3$ ). The coordinates of the site are N $28^{\circ} 43^{\prime} 31^{\prime \prime}$ and W $009^{\circ} 36^{\prime} 31^{\prime \prime}$ - Altitude $689 \mathrm{~m}$.

The following trilobite species also appear in this outcrop: Lehua tahirii Corbacho, 2008; Lehua sp. and Megistaspis (E.) hammondi forteyi Corbacho \& Vela, 2010; Platypeltoides cuervoae (Corbacho \& López-Soriano, 2012); and Parabathycheilus gallicus Dean, 1965.

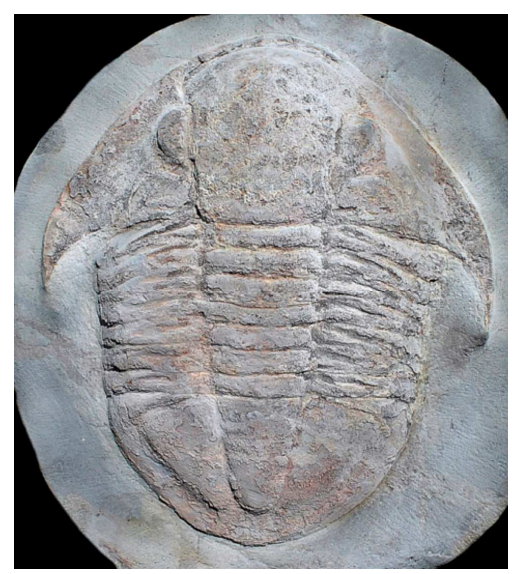

Figure 4. Platypeltoides carmenae. Outcrop $n^{\circ} 3, N W$ de Assa in Guelmim area. Holotype $n^{\circ}$ NHMUK It 29220. Picture taken from [2].

\subsection{Platypeltoides cuervoae (Corbacho \& López-Soriano, 2012)}

2012 - Asaphellus cuervoae Corbacho \& López-Soriano, pag. 4, plates $1-3$

2014 - Asaphellus cuervoae Corbacho \& Calzada, pag. 22, plate 1

2018 - Asaphellus cuervoae Lebrun [54], pag. 83, fig. D

Diagnosis - Platypeltoides species of medium size, characterized by large eyes (approximately $30 \%$ of the glabellar length), with long and wide genal spines extending perpendicularly from the cephalon and making a $90^{\circ}$ angle with the axis (sag.); the spines slightly towards their terminal 
part. The other characteristics are typical of the genus Platypeltoides.

Material - Four specimens are presented. The holotype, with a length of $125 \mathrm{~mm}$, is kept in the Natural History Museum of London (UK) under the annotation NHMUKit28944. A paratype, with a length of $115 \mathrm{~mm}$, is kept in the Natural History Museum of London (UK) under the annotation NHMUK-it28945. Two additional paratypes, with a total length of $120 \mathrm{~mm}$ and $95 \mathrm{~mm}$, are kept in the collection of Joan Corbacho in the Museo Geológico del Seminario de Barcelona (Spain), under the annotations MGSB-JC76 and MGSB-JC77 respectively.

Geographical distribution - The studied locality consists of grey-blue ferruginous sandstones which have been assigned to the Upper part of the Lower Fezouata Formation, Lower Ordovician (Upper part of Tremadocian). The studied site is located approximately $710 \mathrm{~km}$ of the SW of Rabat, in the administrative area of Agadir and NW of Assa in Guelmim area; Western Anti-Atlas, Morocco (Figure 1, locality $\mathrm{n}^{\circ} 3$ ). The coordinates of the site are N $28^{\circ} 43^{\prime} 31^{\prime \prime}$ and W $009^{\circ} 36^{\prime} 31^{\prime \prime}$ - Altitude $689 \mathrm{~m}$.

The following trilobite species also appear in this outcrop: Lehua tahirii Corbacho, 2008; Lehua sp. and Megistaspis (E.) hammondi forteyi Corbacho \& Vela, 2010; Platypeltoides carmenae Corbacho et al. 2017; and Parabathycheilus gallicus Dean, 1965.

Discussion - When this species was first described, the extremely long genal spines and other particular characteristics caused us to underestimate the importance of the number of segments, and for this reason it was assigned to the genus Asaphellus. With the study of new complete and well-preserved specimens, it has been proven that they only have 7 thoracic segments, so they should be assigned to the genus Platypeltoides.

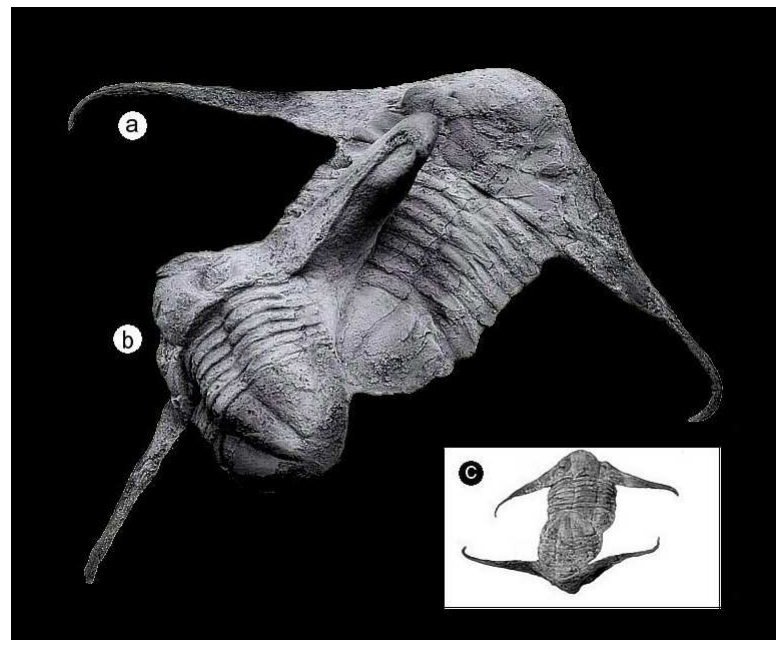

Figure 5. Platypeltoides cuervoae. Outcrop $n^{\circ} 3, N W$ de Assa in Guelmim area. (a) paratype $n^{\circ} M G S B-J C 76$, (b) paratype $n^{\circ} M G S B-J C 77$, (c) holotype $n^{\circ}$ NHMUK-it28944 and paratype $n^{\circ}$ NHMUK-it28945. Picture taken from [48].

\subsection{Platypeltoides aff. carmenae Corbacho et al., 2017}

2017 Platypeltoides aff. carmenae Corbacho et al., pag. 21
Diagnosis - Platypeltoides of large size, with a slightly subtriangular-shaped cephalon and medium-sized genal spines, large eyes located in the transverse median line of the cranidium, a narrow border and a subtriangular pygidium with three axial rings and a terminal axial piece [2].

Material - A single specimen with a total carapace length of $155 \mathrm{~mm}$ is included. It is kept in the collection of Keith Hammond in the Museo Geológico del Seminario de Barcelona (Spain), under the annotation MGSB-KH2b.

Geographical distribution - Upper part of the Lower Fezouata Formation. The studied locality exposes blue green argillites from the Upper Tremadocian. The locality yielding the new trilobite is located approximately $21 \mathrm{~km}$ al $\mathrm{N}$ de Zagora, Dra Valley, Morocco (Figure 1, locality $\mathrm{n}^{\mathrm{o}} 2$ ). The coordinates of the site are N 30'30'54" - W 5 $455^{\prime} 24^{\prime \prime}$ Altitude $804 \mathrm{~m}$.

The following trilobite species also appear in this outcrop: See figure 6.

Discusion - Because only one specimen is available, it is left in open nomenclature.

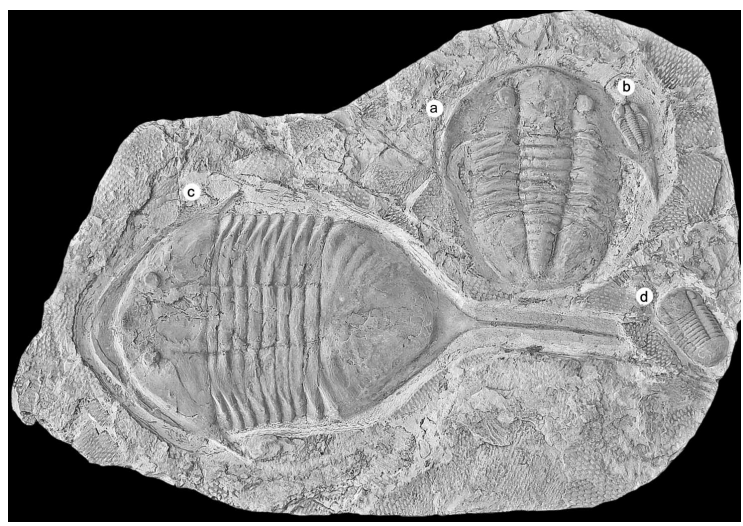

Figure 6. (a) Platypeltoides aff. carmenae. Outcrop $n^{\circ} 2$, North of Zagora, Dra Valley, $n^{\circ}$ MGSB-KH2a; (b) Parathycheilus gallicus Dean, $1965 n^{\circ}$ MGSB-KH2b; (c) Megistaspis (E.) hammondi $n^{\circ} M G S B-K H 2 c$ and (d) Symphysurus angustatus Boeck, $1838 n^{\circ} M G S B-K H 2 d$.

\subsection{Platypeltoides sp.}

Material - A single specimen with a total carapace length of $56 \mathrm{~mm}$ is included. It is kept in the collection of Joan Corbacho in the Museo Geológico del Seminario de Barcelona (Spain), under the annotation MGSB- JC561.

Geographical distribution - Upper part of the Lower Fezouata Formation. The studied locality exposes blue green argillites from the Upper Tremadocian. The locality yielding the new trilobite is located approximately $21 \mathrm{~km}$ al $\mathrm{N}$ de Zagora, Dra Valley, Morocco (Figure 1, locality $\mathrm{n}^{\circ} 2$ ). The coordinates of the site are N 30'30'54" - W 5'45'24" Altitude $804 \mathrm{~m}$.

The following trilobite species also appear in this outcrop: Megistaspis (E.) hammondi Corbacho \& Vela, 2010; Platypeltoides aff. carmenae Corbacho et al., 2017; Parabathycheilus gallicus Dean, 1965; and Symphysurus angustatus Boeck, 1838. 


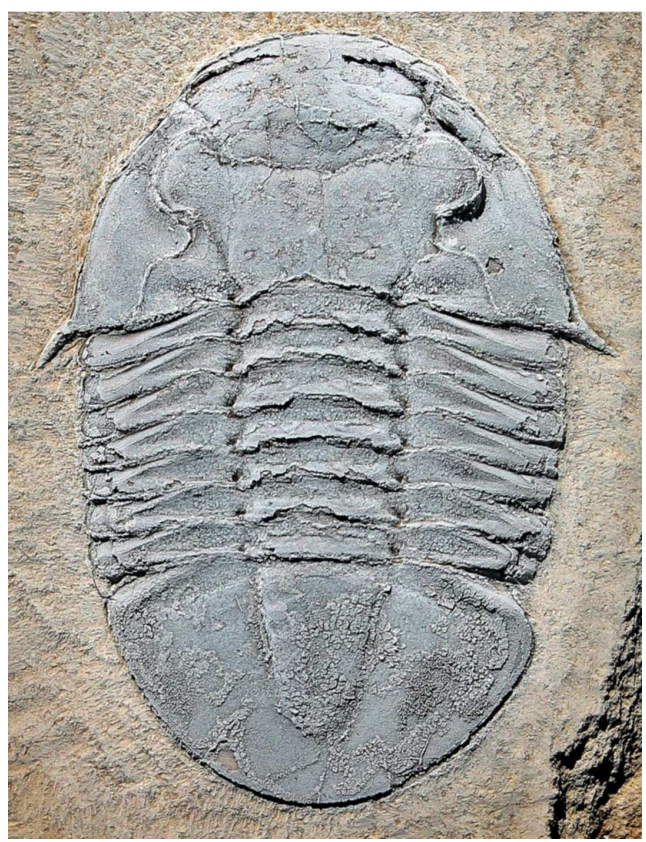

Figure 7. Platypeltoides sp. $n^{o}$ MGSB-JC561. Outcrop $n^{o} 2$, North of Zagora, Dra Valley.

Discussion - Only one specimen is available. Here we propose that it could be a juvenile specimen because of the large size of its eyes, as it also occurs with the holotype of $P$. magrebiensis?, which is a holaspis (Plate 1, fig. b) since the length of their carapaces are almost equal. The small spines that it presents are normal in the juvenile specimens of some species of Platypeltoides, that are subsequently lost when arriving at the adult phase of development. For these reasons, it is left in open nomenclature.

\section{Conclusion}

Regarding the diversity of the genus Platypeltoides, four described species and two possible new species to be described are included in this report. In Morocco, until 2016, only Platypeltoides magrebiensis? was recorded in the Zagora region, but this study shows that the distribution of Platypeltoides is concentrated both in the Zagora region and in the Guelmim area. All them appear in the Lower Fezouata Formation (Tremadocian), Lower Ordovician. The presence of well developed genal spines in adult specimens is a very particular characteristic of the species $P$. hammondi, $P$. cuervoae and $P$. carmenae; they are the only three species in which this characteristic has been observed in this genus.

\section{Acknowledgements}

We would like to express our gratitude to the staff of the Museo Geológico del Seminario de Barcelona (Spain) for the constructive criticism of this document. We would like to thank Brahim Tahiri and Mohamed Ahchach of the Paleontological Museum Arfoud (Morocco), and Hassain of Taichoute (Morocco), for the obtaining, work of extraction of the studied specimens and their field aid. Also our thanks to all the staff of the Xaluca group for their support and hospitality.

\section{References}

[1] J. Corbacho, and F. J. López-Soriano (2016) Platypeltoides hammondi (Trilobita, Nileidae): A new species from the Upper Tremadoc of the Dra Valley, Morocco. Batalleria 23: 11-19.

[2] J. Corbacho, F. J. López-Soriano, U. Lemke, and K. Hammond (2017) Platypeltoides carmenae: A new Nileidae (Trilobita) from the Lower Ordovician (Tremadocian) of Guelmim area; Western Anti-Atlas, Morocco. Batalleria 25: 20-29.

[3] H. Coquand (1847) Description géologique de la partie septentrionale de l'Empire du Maroc. Bull. Soc. Geol. France 4: 1188-1249.

[4] L. Neltner (1929) Etat des connaissances actuelles sur la géologie du Maroc. C. R. 15ème. Congr. Géol. Int. Pretoria 2: $550-556$.

[5] D. Bigot, and G. Dubois (1931) Sur la présence de l'Ordovicien dans l'Anti-Atlas marocain. C. R. Acad. Sci. Paris 193: 282-293.

[6] H. Termier (1936) Etudes géologiques sur le Maroc central et le Moyen-Atlas septentrional. Notes Mém. Serv. Géol. Maroc 33: $1-156$.

[7] J. C. Barthoux (1924) Les massifs de Djebilet et des Rehamna (Maroc). C. R. Acad. Sci. Paris 179: 504-506.

[8] H. Termier (1927) Observations nouvelles en Maroc central. C. R. Somm. Soc. Géol. France 9: 100-102.

[9] E. Roch (1930) Etudes géologiques dans la région méridionale du Maroc occidental. Mém. Serv. Géol. Maroc 9: 1-542.

[10] J. Destombes (1963) Quelques nouveaux Phacopina (trilobites) de l'Ordovicien supérieur de l'Anti-Atlas (Maroc). Notes Serv. Géol. Maroc 23: 172, 1963.

[11] J. Destombes (1966) Quelques Calymenina (Trilobitae) de l'Ordovicien moyen et supérieur de l'Anti-Atlas (Maroc). Notes Serv. Géol, Maroc 26: 33-44.

[12] J. Destombes (1967) Distribution et affinités des genres de trilobites de l'Ordovicien de l'Anti-Atlas (Maroc). C. R. Somm. Soc. Géol. 4: 133-134.

[13] J. Destombes (1971). L'Ordovicien au Maroc. Essai de synthèse stratigraphique. Mém. Bur. Rech. Géol. Min. 73: 237-263.

[14] J. Destombes, H. Hollard, and S. Willefert (1985) Lower Palaeozoic rocks of Morocco. In Hollard, H. (ed.). Lower Palaeozoic Rocks of the World. Volume 4. Lower Palaeozoic of North-western and West-central Africa. Wiley, New York, pp. 91-336.

[15] I. Rábano (1990) Trilobites del Museo GeoMinero. I. Platypeltoides magrebiensis n. sp. (Asaphina, Nileidae), del Ordovícico inferior del Anti-Atlas central (Marruecos). Boletin Geol. Minero 101: 21-27.

[16] J. A. Vela, and J. Corbacho (2009) New trilobites from Upper Ordovician of El Kaid Errami (Morocco). Batalleria. 14: 99-106. 
[17] J. Corbacho (2011) Upper Ordovician trilobites of Bou Nemrou - El Kaid Errami (Morocco). Batalleria 16: 16-36.

[18] J. Corbacho, and C. Kier (2011) Trilobites of a new outcrop of Upper Ordovician in Jbel Tijarfaïouine, El Kaid Errami (Morocco), with first mention of genus Corrugatagnostus. Scripta Musei Geologici Seminarii Barcinonensis [Ser. palaeontologica] 10: 7-22.

[19] F. J. López-Soriano, and J. Corbacho (2012) A new species of Symphysops from the Upper Ordovician (Lower Ashgill) of Morocco. Batalleria 17: 13-20.

[20] J. Corbacho, and F. J. López-Soriano (2013) Chattiaspis? budili: A new Dalmanitidae species from Morocco; Upper Ordovician (Lower Katian). Batalleria 19: 6-12.

[21] J. Corbacho, and S. Calzada (2014) Posible dimorfismo sexual en Trilobites del Ordovícico inferior. Batalleria 21: 22-26.

[22] J. Corbacho, S. Morrison, and A. Ait Addi (2014) Dionide carlottae: Una nueva especie de Dionididae (Trilobita) del Ordovícico superior de Marruecos. Batalleria 21: 13-21.

[23] R. A. Fortey, and G. D. Edgecombe (2017) An Upper Ordovician (Katian) trilobite fauna from the Lower Ktaoua Formation, Morocco. Bull. Geosci. 92: 1-12.

[24] E. Roch (1939) Description géologique des montagnes à l'Est de Marrakech. Notes Mém. Serv. Géol. Maroc 51: 1-438.

[25] G. Termier, and H. Termier (1950) Paléontologie marocaine 2 (4). Invertébrés de l'Ere Primaire. Annélides, arthropodes, échinodermes, conularides et graptolithes. Notes Mém. Serv. Géol. Maroc 79: 1-279.

[26] G. Choubert, J. Hindermeyer, and P. Hupé (1955) Découverte du Trémadoc dans l'Anti-Atlas (Maroc). C. R. Acad. Sci. Paris 241: $1592-1594$.

[27] J. Destombes (1962) Stratigraphie et paléogéographie de l'Ordovicien de l'Anti-Atlas (Maroc): un essai de synthèse. Bull. Soc. Géol. France 7: 453-460.

[28] J. Destombes (1972) Les trilobites du sous-ordre des Phacopina de l'Ordovicien de l'Anti-Atlas (Maroc). Notes Mém. Serv. Géol. Maroc 32: 1-114.

[29] J. Destombes (2006) Carte géologique au 200000 de l'Anti-Atlas marocain. Paléozoïque inférieur. Cambrien moyen et supérieurOrdovicien-base du Silurien. Sommaire général sur les Mémoires explicatifs des cartes géologiques au 1/200 000 de l'Anti-Atlas marocain. Notes Mém. Serv. Géol. Maroc 515 (149pp.).

[30] J. Destombes (2006) Carte géologique au 1/200 000 de l'AntiAtlas marocain. Paléozoïque inférieur. Cambrien moyen et supérieur-Ordovicien-base du Silurien. Feuille Zagora-Coude du Dra. Mémoire explicatif, Chapitre A [written in 1983]. Notes Mém. Serv. Géol. Maroc 273 (bis, 36 pp.).

[31] J. Destombes (2006) Carte géologique au 1/200000 de l'AntiAtlas marocain. Paléozoïque inférieur. Cambrien moyen et supérieur-Ordovicien-base du Silurien. Feuille Bou HaiaraZegdou. Mémoire explicatif, Chapitre B [written in 1983]. Notes Mém. Serv. Géol. Maroc 259 (bis, 30 pp.).

[32] J. Destombes (2006) Carte géologique au 1/200 000 de l'AntiAtlas marocain. Paléozoïque inférieur. Cambrien moyen et supérieur-Ordovicien-base du Silurien. Feuille Jbel SaghroDadès. Mémoire explicatif, Chapitre C [written in 1983]. Notes Mém. Serv. Géol. Maroc 161 (bis, 41 pp.).
[33] J. Destombes (2006) Carte géologique au 1/200 000 de l'AntiAtlas marocain. Notice explicative. Paléozoïque inférieur. Cambrien moyen et supérieur-Ordovicien-base du Silurien. Feuille Todrha- Maïder. Mémoire explicatif, Chapitre D [written in 1985]. Notes Mém. Serv. Géol. Maroc 243 (bis, 58 pp.).

[34] J. Destombes (2006) Carte géologique au 200000 de l'AntiAtlas marocain. Paléozoïque inférieur (Cambrien moyen et supérieur-Ordovicien-base du Silurien). Feuille Tafilalt-Taouz. Mémoire explicatif, Chapitre E (Anti-Atlas oriental) [written in 1987]. Notes Mém. Serv. Géol. Maroc 244 (bis, 69 pp.).

[35] J. Destombes (2006) Carte géologique au 1/200 000 de l'AntiAtlas marocain. Paléozoïque inférieur: Cambrien moyen et supérieur-Ordovicien-base du Silurien. Feuille Telouet Sud, Ouarzazate, Alougoum, Agadir-Tissinnt. Mémoire explicatif, Chapitre F [written in 1988]. Notes Mém. Serv. Géol. Maroc 138 (bis, 43 pp.).

[36] M. Vidal (1996) Biofaciès à trilobites dans l'Ordovicien inférieur de l'Anti-Atlas, Maroc: paléoenvironnements et paléobiogéographie. Université de Rennes 1, Unpublished thesis, (142 pp).

[37] M. Vidal (1998) Trilobites (Asaphidae et Raphiphoridae de l'Ordovicien inférieur de l'Anti-Atlas, Maroc. Palaeontogr. Abt. A 251: 39-77.

[38] M. Vidal (1998) Le modèle des biofaciès à trilobites: un test dans l'Ordovicien inférieur de l'Anti-Atlas, Maroc. C. R. Acad. Sci., Paris [Sci. terre planèt.] 327: 327-333.

[39] J. A. Vela (2007) Three new species of Lehua from the Lower Ordovician of Dra Valley (Morocco). Scripta Musei Geologici Seminarii Barcinonensis.[Ser. palaeontologica] 4: 24-37.

[40] J. A. Vela, and J. Corbacho (2007) A new species of Lehua from Lower Ordovician of Dra Valley of Morocco. Batalleria. 13: $78-80$

[41] J. Corbacho (2008) Tres nuevas especies del Género Lehua del Ordovícico Inferior del Valle de Dra (Marruecos). Scripta Musei Geologici Seminarii Barcinonensis [Ser. palaeontologica] 5: 3-13.

[42] R. A. Fortey (2009) A new giant Asaphid trilobite from the Lower Ordovician of Morocco. Mem. Assoc. Australasian Palaeontol. 37: 9-16.

[43] R. A. Fortey (2010) Trilobites of the genus Dikelokephalina from Ordovician Gondwana and Avalonia. Geol. J. 46: 405415 .

[44] R. A. Fortey (2011) The first known complete lichakephalid trilobite, Lower Ordovician of Morocco. Mem. Assoc. Australasian Palaeontol. 42: 1-7.

[45] J. Corbacho, and J. A. Vela (2010) Giant trilobites from Lower Ordovician of Morocco. Batalleria 15: 3-32.

[46] J. Corbacho, and J. A. Vela (2011) Revisión de las especies de Lehua de la región de Zagora (Marruecos). Batalleria 16: 4649.

[47] J. Corbacho, and J. A. Vela (2013) Parvilichas marochii: New genus and species of Lichidae from the Zagora region (Morocco); Early Ordovician (Floian). Scripta Musei Geologici Seminarii Barcinonensis [Ser. palaeontologica] 14: 3-13. 
[48] J. Corbacho, and F. J. López-Soriano (2012) A new asaphid trilobite from the Lower Ordovician (Arenig) of Morocco. Batalleria 17: 3- 12.

[49] M. Basse (2012) Fossilium Catalogus I: Animalia. Pars 150. Trilobites Africae: Catalogus typorum. Margraf Publischers. $311 \mathrm{pp}$.

[50] U. Lemke (2018) Catalogue of the available names and non available names of the species and subspecies for the Class Trilobita. DOI: 10.13140/RG.2.2.16878.72007

[51] J. Destombes, J. Sougy, and S. Willefert (1969) Révision et découvertes paleontològiques (Brachiopodes, Trilobites et Graptolites) dans le Cambro-Ordovicien du Zemmour (Mauritanie Septentriolnale). Bull. Soc. Géol. France 11: 185206.
[52] R. Trompette (2012) Le Precambrien superieur et le Paleozoique inferieur de l'Adrar de Mauritanie (bordure occidentale du bassin de Taoudeni, Afrique de l'Ouest), un exemple de sedimentation de craton. Etude Stratigraphique et Sedimentologique, Tome 2 (Series 2 et 3 ).

[53] S. Peng, G. Geyer, and B. Hamdi (1999) Trilobites from the Shahmirzad section, Alborz Mountains, Iran; their taxonomy, biostratigraphy and bearing for international correlation. Beringeria 25: 3-66.

[54] Lebrun, P. (2018). Fossiles du Maroc. Tome I. Gisements emblématiques du 246 Paléozoïque de l'Anti-Atlas. Fossils from Morocco. Volume I. Emblematic 247 localities from the Palaeozoic of the Anti-Atlas. Les Editions du Piat - Glavenat, 248304 pp. 